\title{
ASSESSMENT OF SPATIAL PROPERTIES OF KARST AREAS ON A REGIONAL SCALE USING GIS AND STATISTICS - THE CASE OF SLOVENIA
}

\author{
Marko Komac And Janko URbanc \\ Geological Survey of Slovenia, Dimičeva ul. 14, SI-1000Ljubljana, Slovenia, marko.komac@geo-zs.si
}

\begin{abstract}
In Slovenia, $43 \%$ of the territory is karst, including $42 \%$ of all protected water sources and $53 \%$ of all water-protection areas in the country. Over $95 \%$ of drinking water is obtained from groundwater, so assessment of karst areas and their spatial distribution is essential to better understand the water in the lithosphere and for the assessment of the hydrogeochemical properties of the groundwater in a large part of Slovenia. These groundwater resources are susceptible to degradation or pollution, and a regional karstification-intensity map was developed to assist in the management of these water resources and to interpret the chemical composition of the groundwater. For the purpose of classifying stratigraphic units into karstification-level classes, three parameters were analyzed in the outcrops of units with carbonate content using GIS and simple spatial statistics: the presences of sinks and cave entrances and the absence of a surficial drainage network. Where at least two of the three parameters showed a positive relation with karstification, the unit was regarded as intensely karstified, while the rest were regarded as less karstified. The former areas cover $24 \%$ and the latter $21 \%$ of Slovenian territory.
\end{abstract}

\section{INTRODUCTION}

Due to its natural features, Slovenia is a cradle of karst research. According to Gams (2003), 43\% of Slovenian territory is karst. Figure 1 (generalized after Gams, 2003) shows the general distribution of karst types in Slovenia. Karst is a terrain, generally underlain by limestone or dolomite, in which the topography is chiefly formed by the dissolution of rock and that may be characterized by sinkholes, sinking streams, closed depressions, subterranean drainage, and caves (Monroe, 1970).

Karst areas have very specific hydrogeological properties, and hence, a karst map of high quality is essential for the purpose of better understanding the flow and chemical composition of water in the almost half of Slovenia's territory that consists of carbonate rocks. For the purpose of studying the characteristics of Slovenian aquifers in a later stage, a better and newer map of karst areas on a general scale is needed. Such a map will also be very useful for assessing groundwater vulnerability and siting of ecologically problematic projects, but the intention of this paper is not to address the vulnerability issue. An assessment of these is the next step, which will be done in the future when additional parameters will have to be considered, such as soil cover and the thickness of the vadose zone. The intention of this paper is merely to assign different intensities of karstification to areas in Slovenia on the basis of available data by using GIS methods.

In the past, there were several attempts to map karst areas in Slovenia (among others, Blaeu and Blaeu, 1645; Valvasor, 1977; Gams, 2003), but none were based upon a statistical approach or directly on stratigraphic levels. The recently published Geological map of Slovenia at a scale of 1:250,000 (Buser, 2010) enabled a novel approach to assessing karst-prone areas for the whole Slovenian territory at an acceptable resolution.

Various studies have dealt with the analysis of karst terrains and karst features using GIS, remote-sensing techniques, and field work to derive large-area karst maps. Florea et al. (2002) used systematic mapping of karst features and GIS to produce a karst map of an area of Kentucky. Veni (2002) based his karst (and pseudokarst) map of the United States on lithology, rather than on karst features. Armstrong et al. (2003) analyzed the relation between hydraulic conductivity and karst surface features and found a good correlation between the two in western Florida. Also in Florida, Denizman (2003) investigated morphometric parameters of karst surface features and concluded that GIS provides good tools for karst studies. Florea (2005) used sinkhole information to identify known and unknown structural features in Kentucky. For the smaller area in Kentucky, Taylor et al. (2005) derived sinkhole data from digital elevation models. Stafford et al. (2008) used karst features data to develop a karst-potential map in evaporates. They discovered that using a GIS approach exclusively underestimates the actual extent and development of karst features. Gao and Zhou (2008) gave a thorough overview of past GIS and database application in karst research.

\section{Study Area}

Slovenia lies in central Europe, at the contact of the Alpine arch with the Dinaric chain and Pannonian basin. Its surface measures slightly over $20,200 \mathrm{~km}^{2}$ (Fig. 2). Elevations extend from sea level up to $2864 \mathrm{~m}$, and the landscape varies from Pannonian plains to hilly slopes and Alpine mountains, 


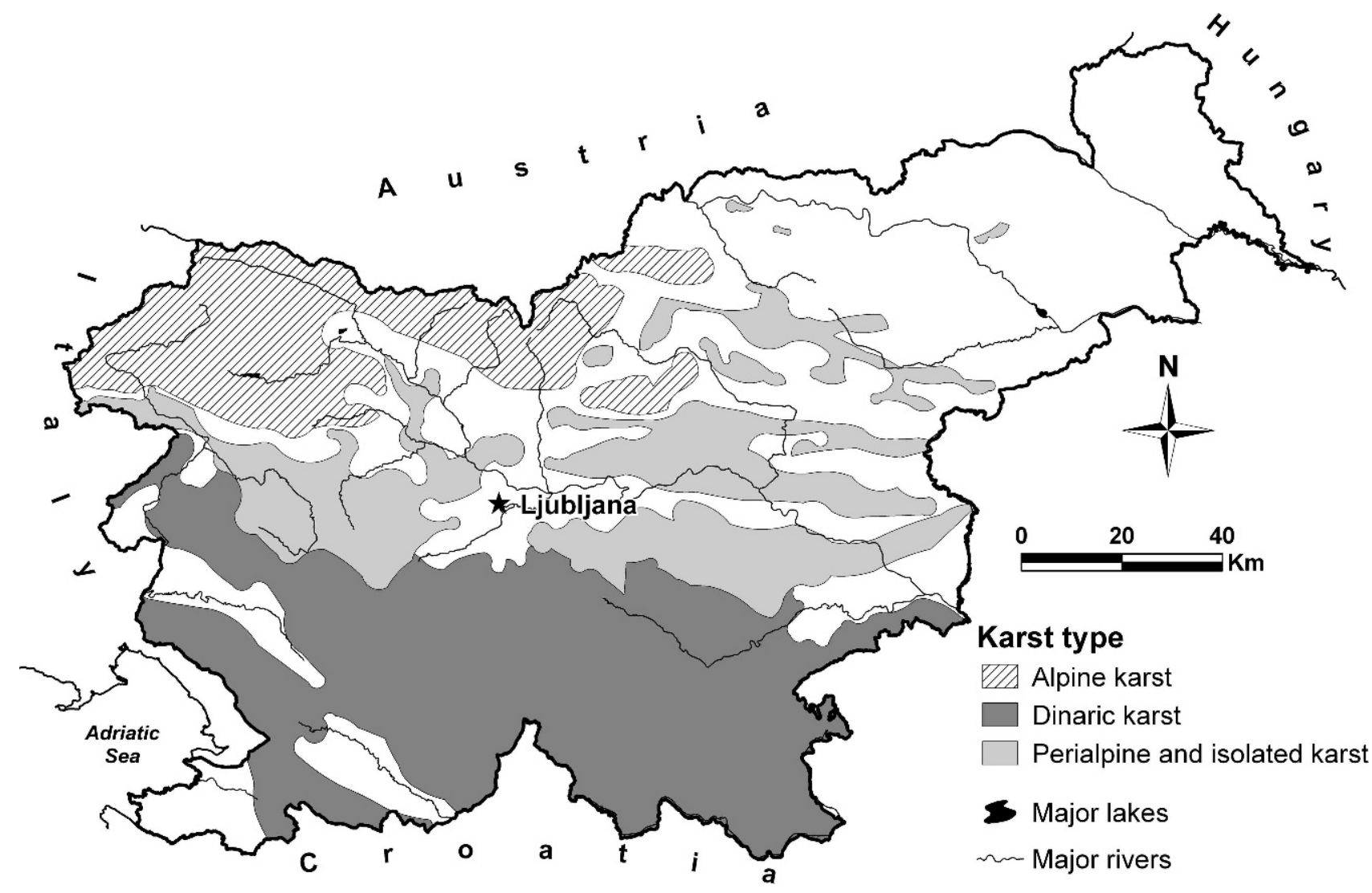

Figure 1. Karst regions in Slovenia, generalized after Gams (2003).

all with areas of karst morphology. Due to its richness in carbonate formations, more than $40 \%$ of Slovenia is karst or semi-karst. According to Komac (2005) almost $92 \%$ of the carbonates are of Mesozoic age in Slovenia, where karst is only developed on carbonate rocks. Of the territory of Slovenia, $49.25 \%$ is composed of clastic rocks, carbonate rocks cover $39.31 \%$, and a mixture of the two covers $4.27 \%$ of the area. The least area is occupied by igneous rocks $(1.49 \%)$, followed by pyroclastic rocks $(1.78 \%)$ and metamorphic rocks (3.9\%). In Slovenia, almost all karst phenomena are the product of hypergenic karst processes, and there is virtually no hypogenic karst.

\section{Data And Methods Used}

The analysis potentially covered the area of the whole country, and a reasonable scale for the data was selected. The digital Geological Map of Slovenia at a scale of 1:250,000 (Buser, 2010) in ESRI shape format was used as a basis for stratigraphic information. Lithologies of the strata and thicknesses mentioned in the text were obtained from the booklets accompanying the geological maps at a scale of 1:100,000. A digital elevation model with a cell size of 25 meters (GURS, 2005) was used for morphologic analyses, particularly for sink occurrence. The chosen DEM is the best available raw and unbiased information on Slovenia's surface, and, due to the scale and coarse positional precision of the lithologic data, a
$25 \mathrm{~m}$ DEM was detailed enough. We are aware that more precise results could be achieved with more detailed data, but for the purpose of the project, the chosen scale and resolution were satisfactory. Drainage network data at a scale at 1:50,000 were obtained from the Environmental Agency (ARSO, 2005) and used to assess the abundance of surface water flows. A highly detailed catalog of cave entrance was collected by the Speleological Association of Slovenia (JZS, 2010). All analyses were conducted with ESRI ArcGIS software.

The approach we chose was based on surface karst features. Because of the resolution and other limitations in the input datasets, a combination of three factors, cave, sink, and drainage-network densities, was chosen as a measure of karstification intensity. The method presented in this paper is obviously applicable only for the assessment of hypergenic karst, while for the purpose of assessment of hypogenic karst its use is very limited.

Before the analyses, all areas selected for the study were classified by an experienced hydrogeologist with long-term experience in karst hydrology as at least potentially karstified areas. The analysis covered the area of the whole country, and a reasonable scale for the data was selected.

Prior to analyses performed in GIS on a $25 \mathrm{~m}$ cell basis, data used in the analyses had to be selected. Given the fact that karst can only develop on soluble rocks (Monroe, 1970), stratigraphic formations were used as the basis for the analysis. For this purpose we extracted from the Geological 


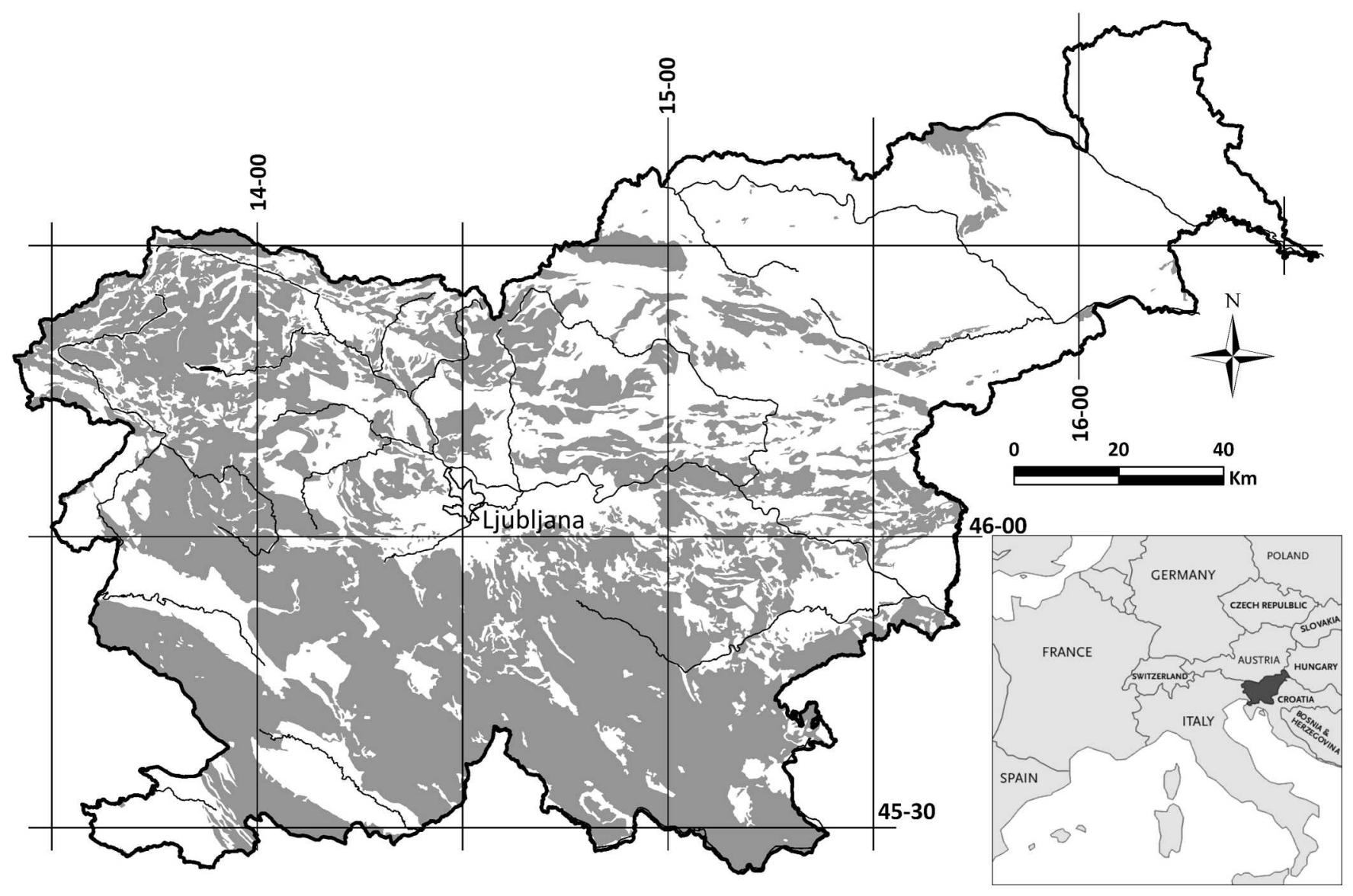

Figure 2. Map of Slovenia with outcrops of selected units shown in gray. Location of Slovenia in Europe is shown in the lower right.

map of Slovenia all stratigraphic formations containing the words limestone, calcite, or dolomite in their lithologic descriptions to get a subgroup of units (and hence outcrop areas) that could be potential carbonate-karst areas. Out of 114 units, 47 were selected, represented by 2048 polygons covering $44.7 \%$ of Slovenia. Purely non-carbonate units were ignored in our study, though several of the selected units contain both carbonate and non-carbonate rocks, mainly clastic rocks. We expected that this simple selection would include some formations that are less susceptible to karstification, as not all were pure carbonates. In fact, in some formations, carbonates are a minor lithology or only occur in small areas and limited thickness, and those may not host frequent or well-developed karst features. In Slovenia, dolomites, which are by definition pure carbonates, are generally not karstified, but rather form fractured aquifers with completely different hydrogeological characteristics than limestone areas. We acknowledge these potential sources of error and also point out that, given the coarse spatial resolution of the DEM and generalization of the stratigraphic map, some small areas of carbonates that do have karst development may not be represented in our analysis. Karst fields (poljes) were not included in this selection since they are stratigraphically classified as Quaternary sediments. Stratigraphic units were classified as one of four lithologic classes, clastic rocks, dolomites, limestones, and mixed limestones and dolomites.

The chosen DEM is the best available raw and unbiased information on Slovenia's surface, and, due to the scale and coarse positional precision of the lithologic data, a $25 \mathrm{~m}$ DEM was detailed enough. We are aware that more precise results could be achieved with more detailed data, but for the purpose of the project, the chosen scale and resolution were satisfactory.

The occurrence of sinks indicates the presence of karst processes. Numbers of sinkholes were derived for the whole study area from the $25 \mathrm{~m}$ DEM using the Sink function in ArcMap software. Obviously not all features derived were karst sinks, because a proportion of them (and the most obvious ones) occurred in flat alluvial basins or in the vicinity of rivers. After a field-check at representative locations, we decided to exclude, in addition to non-carbonate outcrops, areas on alluvial plains within a $75 \mathrm{~m}$ ( 3 cells) buffer zone near rivers. Our fieldwork experience has shown that in the vicinity of rivers no sinks occur, and those derived there from a DEM are artifacts, most probably related to small relic channels or ditches. The buffer zone width was defined by trial, because in many areas - mainly valleysthe alluvial sediments are shown disproportionally narrow 
due to the scale of the geological map and their being of less importance on the geological map than bedrock, especially because there is no surface water flow in valleys in karst areas. Altogether there were 129,485 accepted sink occurrences in the analyzed areas. Density varied from 0 to 43.7 sinks $/ \mathrm{km}^{2}$, with a mean of 10.6 sinks $/ \mathrm{km}^{2}$ and a standard deviation of 11.2. We acknowledge that due to the automatic derivation of the sink data some bias in the form of spurious sinks still exists, especially in flat terrain where alluvial sediments partially composed of carbonate rocks were included in the analysis. Hence the sink-index values of these lithologic units need to be interpreted with caution.

The occurrence of caves is obviously the most definitive proof that an area can be classified as karst. At the same time, the cave data may be biased, since the data were collected by incidental discoveries and generally not by a systematic search of the terrain. Despite its limitations, the cave catalog is the only available resource of this type covering all of Slovenia that could be used in GIS analysis, so it was used as one of the bases for the evaluation of karstification intensity. The cave catalog includes records of entrances to various types and stages of karst caves, fully developed horizontal or sub-horizontal caves, vertical caves, inactive caves, freezing or ice caves, and rock-shelters. The information regarding cave occurrence was the only data set that was used in a raw form for the analyses. There were 7554 cave entrances mapped in the study area. Cave density values varied from 0 to 2.1 caves $/ \mathrm{km}^{2}$, with a mean of $0.6 \mathrm{cave} / \mathrm{km}^{2}$ and a standard deviation of 0.5 .

The absence of a surface drainage network on a given formation can also indicate the presence of karst areas where subsurface drainage is predominant. To avoid losing the information on the surface drainage network density when performing raster-based analyses, we calculated the density of the drainage network by simply dividing the total length of this network by the area of a given stratigraphic unit's outcrop. The total length of surface drainage network with flowing water in the analysis area was $6082.3 \mathrm{~km}$. The surficial drainage network density was expressed in $\mathrm{km} / \mathrm{km}^{2}$, and values varied from 0 to $2.5 \mathrm{~km} / \mathrm{km}^{2}$, with a mean of $0.95 \mathrm{~km} / \mathrm{km}^{2}$ and a standard deviation of 0.75 . Our approach was based on the assumption that lower drainage network densities imply higher karstification intensities.

Table 1 shows the extent of the studied features within each stratigraphic outcrop that was included, as well as its area. The average densities of features in the overall area was 0.83 caves per $\mathrm{km}^{2}, 14.3$ sinks per $\mathrm{km}^{2}$, and $0.67 \mathrm{~km}$ of surface drainage network per $\mathrm{km}^{2}$.

For a quantitative assessment of the importance of the presence of caves or sinks and the absence of surface drainage in each stratigraphic unit, a non-parametric chi-squared $\left(X^{2}\right)$ was computed as $(O-E)^{2} / E$ for each of the observed quantities, where $O$ was the observed quantity and $E$ was the expected value of that quantity in the area of the particular unit based on the average over all units. From this, an index was computed by negating the $X^{2}$ value if $(O-E)$ was negative in the cases of numbers of caves and sinks and if it was positive in the case of drainage networks. (A more extensive drainage network implies less karstification.) Hence in all cases, a negative index indicates that the unit appears less karstified than average based on that particular quantity, and a positive index indicates that the unit appears more karstified. The resulting cave indexes (CI), sink indexes (SI), and surface drainage network indexes (SDNI) are listed in Table 2 and displayed in Figure 3.

For each feature index in each stratigraphic unit, a normalized value was computed. For example, $C I_{\text {norm }}=$ $\left(C I-C I_{\min }\right) /\left(C I_{\max }-C I_{\min }\right)$, where $C I_{\max }$ and $C I_{\min }$ are the maximum and minimum values of $\mathrm{CI}$ observed for any unit. Normalized values for SI and SDNI were computed similarly, and the three normalized values for each unit were averaged to give a single average of normalized indexes (ANI). The ANIs are also listed in Table 2.

All correlation tests were performed using Pearson productmoment correlation coefficient $(r)$ formula, and values represent linear correlation coefficients.

\section{Results AND Discussion}

\section{General Results}

Chi-square analyses showed that the three phenomena we expected to be related to karst areas were the correct choice. For all tests the degrees of freedom (df) was 46. In the case of cave occurrence, $X^{2}$ had the score of 3975.7 and the $p$-value $<0.001$; in the case of sink occurrence, $X^{2}$ had the score of 74070.2 and the $p$-value $<0.001$; and in the case of density of surficial drainage network, $X^{2}$ had the score of 4795.9 and the $p$-value $<0.001$.

For each stratigraphic unit, the number of indexes that were greater than 0 (IIC) is shown in Table 2. An indication of karstification intensity, we presumed that units with IIC $\geq 2$ are intensely karstified, and that other units are less karstified. In most cases, the intensely karstified areas have ANIs that exceed those of the areas less karstified. A threshold of ANI $\geq 0.4344$ coincides rather well with the simplified threshold of at least two positive indexes, except for the units 13 and 48, which have ANI values above that threshold but have only one positive index. The high value of ANI (0.602) for unit 13 is the consequence of very high SI value, while the other two indexes are negative. Despite the fact that in the area of unit 13 the number of sinks is high, the other two indexes indicate that the unit should be classified among the less karstified areas. The reason for a high SI value is probably a combination of errors of the automatically derived sink data and of the fact that parts of the exposure of unit 13 with widely differing intensities of karstification were not separated on the geological map. Unit 48 is a very heterogeneous formation, composed of limestones, marls, and coal and bauxite beds that has, like unit 13, some intensely karstified areas, while in general, the karstification is very limited due to its composition. So 
Table 1. Amounts of inventoried features in each stratigraphic unit and their areas. SDN is length of surface drainage network.

\begin{tabular}{|c|c|c|c|c|}
\hline No. ${ }^{\mathrm{a}}$ & Caves & Sinks & $\mathrm{SDN}, \mathrm{km}$ & Area, $\mathrm{km}^{2}$ \\
\hline 13 & 24 & 6627 & 162.3 & 151.6 \\
\hline 27 & 6 & 450 & 290.5 & 206.9 \\
\hline 29 & 19 & 912 & 155.3 & 171.0 \\
\hline 34 & 0 & 37 & 22.3 & 9.9 \\
\hline 42 & 10 & 166 & 60.2 & 30.4 \\
\hline 45 & 4 & 45 & 1.7 & 1.9 \\
\hline 46 & 181 & 2544 & 72.8 & 188.0 \\
\hline 48 & 92 & 1585 & 28.3 & 112.0 \\
\hline 50 & 2 & 22 & 2.6 & 8.9 \\
\hline 52 & 26 & 405 & 66.7 & 70.4 \\
\hline 53 & 24 & 225 & 81.8 & 81.6 \\
\hline 54 & 186 & 1793 & 18.2 & 104.6 \\
\hline 55 & 8 & 208 & 0.0 & 9.4 \\
\hline 56 & 9 & 100 & 84.6 & 58.7 \\
\hline 57 & 1116 & 11886 & 66.9 & 584.3 \\
\hline 58 & 4 & 294 & 0.0 & 17.6 \\
\hline 59 & 1463 & 28334 & 107.5 & 1097.5 \\
\hline 61 & 543 & 10614 & 26.2 & 334.5 \\
\hline 63 & 13 & 67 & 62.8 & 34.2 \\
\hline 64 & 277 & 7182 & 22.1 & 277.4 \\
\hline 65 & 74 & 4060 & 20.1 & 123.5 \\
\hline 66 & 195 & 8099 & 16.7 & 281.4 \\
\hline 67 & 111 & 4349 & 31.0 & 177.6 \\
\hline 68 & 15 & 34 & 16.6 & 23.6 \\
\hline 70 & 3 & 41 & 18.3 & 9.6 \\
\hline 71 & 333 & 8200 & 38.0 & 333.0 \\
\hline 72 & 324 & 7750 & 85.0 & 390.3 \\
\hline 73 & 3 & 34 & 96.4 & 41.4 \\
\hline 74 & 4 & 292 & 2.8 & 15.1 \\
\hline 75 & 4 & 69 & 5.7 & 15.2 \\
\hline 76 & 1504 & 6617 & 386.1 & 914.3 \\
\hline 77 & 283 & 11177 & 1133.2 & 1096.8 \\
\hline 78 & 20 & 131 & 239.0 & 150.1 \\
\hline 80 & 32 & 447 & 291.5 & 180.6 \\
\hline 81 & 1 & 36 & 38.5 & 25.7 \\
\hline 82 & 0 & 1 & 7.7 & 6.6 \\
\hline 83 & 2 & 27 & 102.9 & 41.9 \\
\hline 84 & 387 & 2247 & 643.3 & 641.1 \\
\hline 85 & 30 & 28 & 54.3 & 45.5 \\
\hline 86 & 11 & 479 & 110.4 & 112.7 \\
\hline 87 & 32 & 290 & 30.7 & 48.8 \\
\hline 91 & 67 & 505 & 458.3 & 325.1 \\
\hline 92 & 85 & 996 & 806.7 & 445.9 \\
\hline 93 & 13 & 50 & 87.7 & 44.7 \\
\hline 96 & 0 & 7 & 2.7 & 1.1 \\
\hline 97 & 11 & 23 & 20.5 & 19.2 \\
\hline 102 & 3 & 0 & 5.7 & 5.1 \\
\hline$\Sigma$ & 7554 & 129485 & 6082.3 & 9066.7 \\
\hline
\end{tabular}

${ }^{a}$ Lithological description of units/formations is given in the second column in Table 2. despite the relatively large values of ANI, the IIC test places both units in the less karstified class.

Analyses of the correlation values $(r)$ between the three sets of indexes show that the connection between cave occurrence and sink occurrence is not very strong $(0.26)$, while the correlation between the absence of surficial drainage network and cave $(0.58)$ or sink (0.66) occurrence is stronger. The weaker correlation value of the cave occurrence could be explained with the fact that caves were not systematically mapped, but were registered by pure chance, and that most probably, there are still some caves to be discovered. Also, the cave data only record entrances and do not reflect the size of the caves. Correlations between the types of indexes might imply that they are not independent; this is in fact expected for hypergenic karst. Although the relations between the studied features may not apply outside the study area, for Slovenia the correlation between the absence of surface drainage network and sink or cave occurrence is a fact that was also checked and proved in the field.

Caves are absent (density $=0.0 \mathrm{~km}^{-2}$ ) in three units (34, $82,96)$, sinks in one (102), and surficial drainage network in two $(55,58)$. The highest density of caves $\left(2.1 \mathrm{~km}^{-2}\right)$ was found in unit 45 , the highest density of sinks $\left(43.7 \mathrm{~km}^{-2}\right)$ in unit 13, and the highest density of surface drainage network $\left(2.45 \mathrm{~km} / \mathrm{km}^{2}\right)$ in unit 83 . Results for the different types of index values can be discussed in more detail with reference to Table 2 and Figure 3 and additional information, not shown, about the lithology of the stratigraphic units.

The composition of units with highly positive value of the cave index $(54,57,59,61,71$, and 76) indicate that these units are either composed of 200 to $1500 \mathrm{~m}$ of relatively pure $\mathrm{CaCO}_{3}$ (units 54, 57, 76), or are composed of $\mathrm{CaCO}_{3}$ and limited impurities, mainly bituminous dolomite (units 59, 61, 71). For units where the other two indexes, SI and SDNI, were negative, low CI values correspond well to the low karstification intensity. When the other two indexes are positive, negative CI values, which from the cave-occurrence perspective indicate less karstified areas, are probably result of random and sporadic cave discovery. In the case of homogeneous carbonate lithologic units, it would be expected that even one cave occurrence would indicate well-developed karst, so that the unit should be classified as intensely karstified. Since almost all lithologic units used in this study were not pure carbonates but rather heterogeneous formations of clastic rocks and carbonates, the assumption that one cave in the stratigraphc unit proves that the whole area of that outcrop is intensely karstified is oversimplified and could be wrong. Even in hypergenic karst, basing the distinction between intensely and less karstified areas strictly on the basis of CI values alone could be misleading because of overlooked caves. This is why supplementary indexes of sinks and surface drainage have been used.

Sink index values for stratigraphic units are in general agreement with their classification according to karstification intensity, except in the case of the Triassic Dachstein limestone (76). Extremely low SI value in the Dachstein limestone 
Table 2. Short statement of the lithology of each stratigraphic unit, and results of the statistical analysis of the data in Table 1. CI, cave index; SI, sink index; SDNI, surface drainage network index; ANI, average normalized index; IIC, number of indexes that are greater than 0 , indicating proneness to karstification; LC, lithological class of the unit $(C=$ clastic rocks; $D=$ dolomite; $\mathrm{L}=$ limestone; $\mathrm{LD}=$ mixed limestone and dolomite). Table is sorted first by increasing IIC and then by increasing ANI.

\begin{tabular}{|c|c|c|c|c|c|c|c|}
\hline No. & Lithological unit (formation) description & CI & SI & SDNI & ANI & IIC & $\mathrm{LC}$ \\
\hline 92 & $\begin{array}{l}\text { Dolomite, micaceous siltstone, sandstone, claystone, } \\
\text { oolitic limestone and dolomite, marlstone, marly } \\
\text { limestone (Lower Triassic) }\end{array}$ & -220.9 & -4531.4 & -861.6 & 0.0720 & 0 & $\mathrm{C}$ \\
\hline 77 & $\begin{array}{l}\text { Thick-bedded Main Dolomite (Upper Triassic - } \\
\text { Norian-Rhaetian) }\end{array}$ & -435.4 & -1284.9 & -214.7 & 0.2390 & 0 & $\mathrm{D}$ \\
\hline 91 & $\begin{array}{l}\text { Thick-bedded and massive dolomite, subordinately } \\
\text { limestone (Middle Triassic - Anisian) }\end{array}$ & -153.4 & -3687.6 & -264.6 & 0.2505 & 0 & $\mathrm{D}$ \\
\hline 84 & $\begin{array}{l}\text { Massive coarse-crystalline dolomite and limestone } \\
\text { (Upper Triassic - Rhaetian) }\end{array}$ & -40.5 & -5213.9 & -105.7 & 0.2856 & 0 & $\mathrm{D}$ \\
\hline 27 & $\begin{array}{l}\text { Lithothamnium limestone, marly limestone and marl } \\
\text { (Middle Miocene - Badenian) }\end{array}$ & -160.6 & -2123.0 & -165.8 & 0.3059 & 0 & $\mathrm{C}$ \\
\hline 80 & $\begin{array}{l}\text { Marly limestone, marlstone, dolomite, shale (Upper } \\
\text { Triassic - Carnian) }\end{array}$ & -93.3 & -1762.9 & -239.4 & 0.3141 & 0 & $\mathrm{C}$ \\
\hline 78 & $\begin{array}{l}\text { Platy Bača Dolomite with chert (Upper Triassic - } \\
\text { Norian-Rhaetian) }\end{array}$ & -88.2 & -1889.2 & -190.1 & 0.3245 & 0 & $\mathrm{D}$ \\
\hline 83 & $\begin{array}{l}\text { Alternation of claystone and sandstone, platy limestone in the } \\
\text { upper part - Amphiclina beds (Upper Triassic - Carnian) }\end{array}$ & -31.1 & -546.2 & -198.7 & 0.3667 & 0 & $\mathrm{C}$ \\
\hline 73 & Platy micritic limestone and calcarenite with chert (Lias) & -28.7 & -525.0 & -169.6 & 0.3747 & 0 & $\mathrm{~L}$ \\
\hline 29 & Lithothamnium limestone (Middle Miocene - Badenian) & -107.0 & -959.3 & -14.3 & 0.3815 & 0 & $\mathrm{~L}$ \\
\hline 93 & $\begin{array}{l}\text { Thick-bedded dolomite, subordinately limestone (Upper } \\
\text { Permian) }\end{array}$ & -15.8 & -542.8 & -110.9 & 0.3918 & 0 & $\mathrm{D}$ \\
\hline 86 & $\begin{array}{l}\text { Massive dolomite, subordinately limestone (Middle and } \\
\text { Upper Triassic - Anisian-Norian) }\end{array}$ & -73.2 & -794.4 & -16.0 & 0.3937 & 0 & $\mathrm{D}$ \\
\hline 56 & $\begin{array}{l}\text { Platy limestone with chert in alternation with red } \\
\text { marlstone - Krško beds (Upper Cretaceous - Upper } \\
\text { Cenomanian-Turonian) }\end{array}$ & -32.6 & -650.7 & -51.8 & 0.3991 & 0 & $\mathrm{C}$ \\
\hline 53 & $\begin{array}{l}\text { Platy Volče limestone with chert, red marly limestone and } \\
\text { marlstone (Upper Cretaceous - Coniacian-Campanian) }\end{array}$ & -28.5 & -759.4 & -13.3 & 0.4070 & 0 & $\mathrm{C}$ \\
\hline 63 & $\begin{array}{l}\text { Platy Biancone limestone with chert (Upper Jurassic- } \\
\text { Lower Cretaceous - Tithonian-Berriasian) }\end{array}$ & -8.4 & -362.9 & -69.5 & 0.4075 & 0 & $\mathrm{~L}$ \\
\hline 42 & $\begin{array}{l}\text { Limestone-dolomite conglomerate - Škofja Loka and } \\
\text { Okonina Conglomerate (Middle Oligocene - Rupelian) }\end{array}$ & -9.3 & -165.6 & -77.7 & 0.4096 & 0 & $\mathrm{C}$ \\
\hline 81 & $\begin{array}{l}\text { Platy limestone and dolomite with chert. marlstone. marly } \\
\text { limestone - Tamar Formation (Upper Triassic - Carnian) }\end{array}$ & -19.4 & -298.0 & -26.3 & 0.4163 & 0 & $\mathrm{C}$ \\
\hline 85 & $\begin{array}{l}\text { Massive Wetterstein Limestone and dolomite. thick-bedded } \\
\text { limestone (Middle and Upper Triassic - Ladinian-Cordevol) }\end{array}$ & -1.7 & -595.6 & -18.5 & 0.4164 & 0 & LD \\
\hline 52 & $\begin{array}{l}\text { Coarse-grained limestone breccia with intercalations of } \\
\text { flysch (Upper Cretaceous - Maastrichtian) }\end{array}$ & -18.2 & -358.3 & -8.0 & 0.4197 & 0 & $\mathrm{C}$ \\
\hline 34 & $\begin{array}{l}\text { Lithothamnium-Lepidocyclina limestone, sand, silt and } \\
\text { clay (Lower Miocene - Ottnangian-Eggenburgian) }\end{array}$ & -8.2 & -76.4 & -37.0 & 0.4215 & 0 & $\mathrm{C}$ \\
\hline 70 & Massive crinoidal and oolitic limestone (Lias. Dogger) & -3.2 & -67.9 & -21.6 & 0.4267 & 0 & $\mathrm{~L}$ \\
\hline 97 & $\begin{array}{l}\text { Light-gray to red limestone - Dovžanova soteska and } \\
\text { Trogkofel Formations (Lower Permian) }\end{array}$ & -1.5 & -229.6 & -4.5 & 0.4277 & 0 & $\mathrm{~L}$ \\
\hline 68 & $\begin{array}{l}\text { Reddish and greyish nodular limestone of Ammonitico } \\
\text { Rosso type limestone breccias, marlstone and } \\
\text { claystone (Upper and Lower Jurassic) }\end{array}$ & -1.1 & -273.1 & 0.0 & 0.4280 & 0 & $\mathrm{C}$ \\
\hline 82 & $\begin{array}{l}\text { Chert, platy limestone, claystone and siltstone - Kobla } \\
\text { Formation (Upper Triassic - Carnian) }\end{array}$ & -5.5 & -92.9 & -2.4 & 0.4301 & 0 & $\mathrm{C}$ \\
\hline
\end{tabular}


Table 2. Continued.

\begin{tabular}{|c|c|c|c|c|c|c|c|}
\hline No. & Lithological unit (formation) description & $\mathrm{CI}$ & SI & SDNI & ANI & IIC & $\mathrm{LC}$ \\
\hline 102 & $\begin{array}{l}\text { Thick-bedded limestone in the lower part, reef limestone } \\
\text { in the middle part, thick-bedded micritic limestone in } \\
\text { the upper part (Devonian) }\end{array}$ & -0.4 & -72.7 & -1.5 & 0.4321 & 0 & $\mathrm{~L}$ \\
\hline 96 & $\begin{array}{l}\text { Neoschwagerina reef limestone, limestone breccia } \\
\text { (Middle Permian) }\end{array}$ & -0.9 & -4.8 & -5.2 & 0.4326 & 0 & $\mathrm{~L}$ \\
\hline 87 & $\begin{array}{l}\text { Platy micritic limestone with chert nodules - Pokljuka } \\
\text { Formation (Middle and Upper Triassic) }\end{array}$ & -1.8 & -237.3 & 0.1 & 0.4286 & 1 & $\mathrm{~L}$ \\
\hline 75 & Reef limestone with corals (Upper Triassic - Rhaetian) & -5.9 & -100.9 & 2.0 & 0.4309 & 1 & $\mathrm{~L}$ \\
\hline 50 & $\begin{array}{l}\text { Reddish and gray marly limestone and marlstone } \\
\text { (Turonian-Campanian) }\end{array}$ & -4.0 & -87.3 & 1.9 & 0.4317 & 1 & $\mathrm{C}$ \\
\hline 48 & $\begin{array}{l}\text { Thick-bedded micritic limestone - Vreme and Kozina } \\
\text { beds (Lower Paleocene - Upper Cretaceous - Danian- } \\
\text { Maastrichtian) }\end{array}$ & 0.0 & -0.1 & 29.2 & 0.4411 & 1 & $\mathrm{~L}$ \\
\hline 13 & $\begin{array}{l}\text { Coherent fluvial deposits; terraces (limestone } \\
\text { conglomerate with gravel intercalations) (Quaternar) }\end{array}$ & -82.9 & 9195.7 & -36.1 & 0.6020 & 1 & $\mathrm{C}$ \\
\hline 74 & $\begin{array}{l}\text { Limestone, dolomite and limestone-dolomite breccia (Upper } \\
\text { Triassic and Lower Jurassic (Rhaetian and Lias)) }\end{array}$ & -5.9 & 26.9 & 5.3 & 0.4344 & 2 & LD \\
\hline 58 & $\begin{array}{l}\text { Platy limestone with chert - Komen beds (Upper Cretaceous - } \\
\text { Upper Cenomanian-Turonian) }\end{array}$ & -7.7 & 7.4 & 11.8 & 0.4351 & 2 & $\mathrm{~L}$ \\
\hline 45 & Alveolina-nummulites limestone (Middle Eocene) & 3.8 & 12.4 & -0.2 & 0.4354 & 2 & $\mathrm{~L}$ \\
\hline 46 & Alveolina-nummulites and miliolida limestone (Lower Eocene) & 3.8 & -7.4 & 22.5 & 0.4404 & 2 & $\mathrm{~L}$ \\
\hline 67 & $\begin{array}{l}\text { Reef limestone with corals, hydrozoans and sponges } \\
\text { (Lower part of Upper Jurassic - Lower Kimeridgian- } \\
\text { Oxfordian) }\end{array}$ & -9.3 & 1294.2 & 65.2 & 0.4752 & 2 & $\mathrm{~L}$ \\
\hline 72 & $\begin{array}{l}\text { Micritic and oolitic limestone, limestone breccia and } \\
\text { bituminous dolomite (Lower and Middle Lias) }\end{array}$ & 0.0 & 849.8 & 119.4 & 0.4810 & 2 & LD \\
\hline 65 & $\begin{array}{l}\text { Oolitic and micritic limestone (Upper part of Upper } \\
\text { Jurassic - Upper Kimeridgian-Tithonian) }\end{array}$ & -8.1 & 2986.7 & 47.5 & 0.5078 & 2 & $\mathrm{~L}$ \\
\hline 66 & $\begin{array}{l}\text { Thick-bedded micritic and oolitic limestone (Lower part of } \\
\text { Upper Jurassic - Lower Kimeridgian-Oxfordian) }\end{array}$ & -6.6 & 4142.5 & 156.9 & 0.5592 & 2 & $\mathrm{~L}$ \\
\hline 76 & $\begin{array}{l}\text { Thick-bedded Dachstein Limestone with transitions to } \\
\text { dolomite (Upper Triassic - Norian-Rhaetian) }\end{array}$ & 723.1 & -3177.2 & 84.2 & 0.5787 & 2 & $\mathrm{~L}$ \\
\hline 55 & $\begin{array}{l}\text { Platy limestone with chert - Dutovlje Formation (Upper } \\
\text { Cretaceous - Campanian) }\end{array}$ & 0.0 & 40.8 & 6.3 & 0.4365 & 3 & $\mathrm{~L}$ \\
\hline 54 & $\begin{array}{l}\text { Rudist limestone and calcarenite - Lipica Formation (Upper } \\
\text { Cretaceous - Coniacian-Campanian) }\end{array}$ & 112.2 & 60.1 & 38.5 & 0.4746 & 3 & $\mathrm{~L}$ \\
\hline 64 & $\begin{array}{l}\text { Alternation of dolomite and limestone (Upper part of } \\
\text { Upper Jurassic - Upper Kimeridgian-Tithonian) }\end{array}$ & 9.1 & 2617.2 & 144.5 & 0.5275 & 3 & LD \\
\hline 71 & $\begin{array}{l}\text { Micritic and oolitic limestone, bituminous dolomite (Upper } \\
\text { Lias-Dogger) }\end{array}$ & 11.1 & 2495.1 & 153.9 & 0.5277 & 3 & LD \\
\hline 61 & $\begin{array}{l}\text { Alternation of limestone and dolomite (lower part). micritic } \\
\text { limestone (upper part) (Lower Cretaceous - Berriasian- } \\
\text { Barremian) }\end{array}$ & 250.7 & 7132.8 & 175.0 & 0.6968 & 3 & LD \\
\hline 57 & $\begin{array}{l}\text { Rudist and micritic limestone - Sežana Formation (Upper } \\
\text { Cretaceous - Turonian) }\end{array}$ & 813.3 & 1503.3 & 269.5 & 0.7480 & 3 & $\mathrm{~L}$ \\
\hline 59 & $\begin{array}{l}\text { Thick-bedded micritic limestone and bituminous dolomite } \\
\text { (Lower Cretaceous and lower part of Upper Cretaceous) }\end{array}$ & 329.2 & 10226.7 & 536.8 & 0.8708 & 3 & LD \\
\hline
\end{tabular}

could be explained by the fact that the average slope angle of this unit is $26.4^{\circ}$, while average slope angles of other intensive karst areas are below $13^{\circ}$. For the intensely karstified outcrops analyzed in this paper, the correlation between the number of sinks in a given slope angle class and the area of the same slope angle classes was 0.79 . The distribution of the slope angle classes' areas correlates well with the distribution of sinks; hence this dependence can be used to test the correlation between slope angle and sink distribution. Correlation test of the later showed that at higher slopes the 


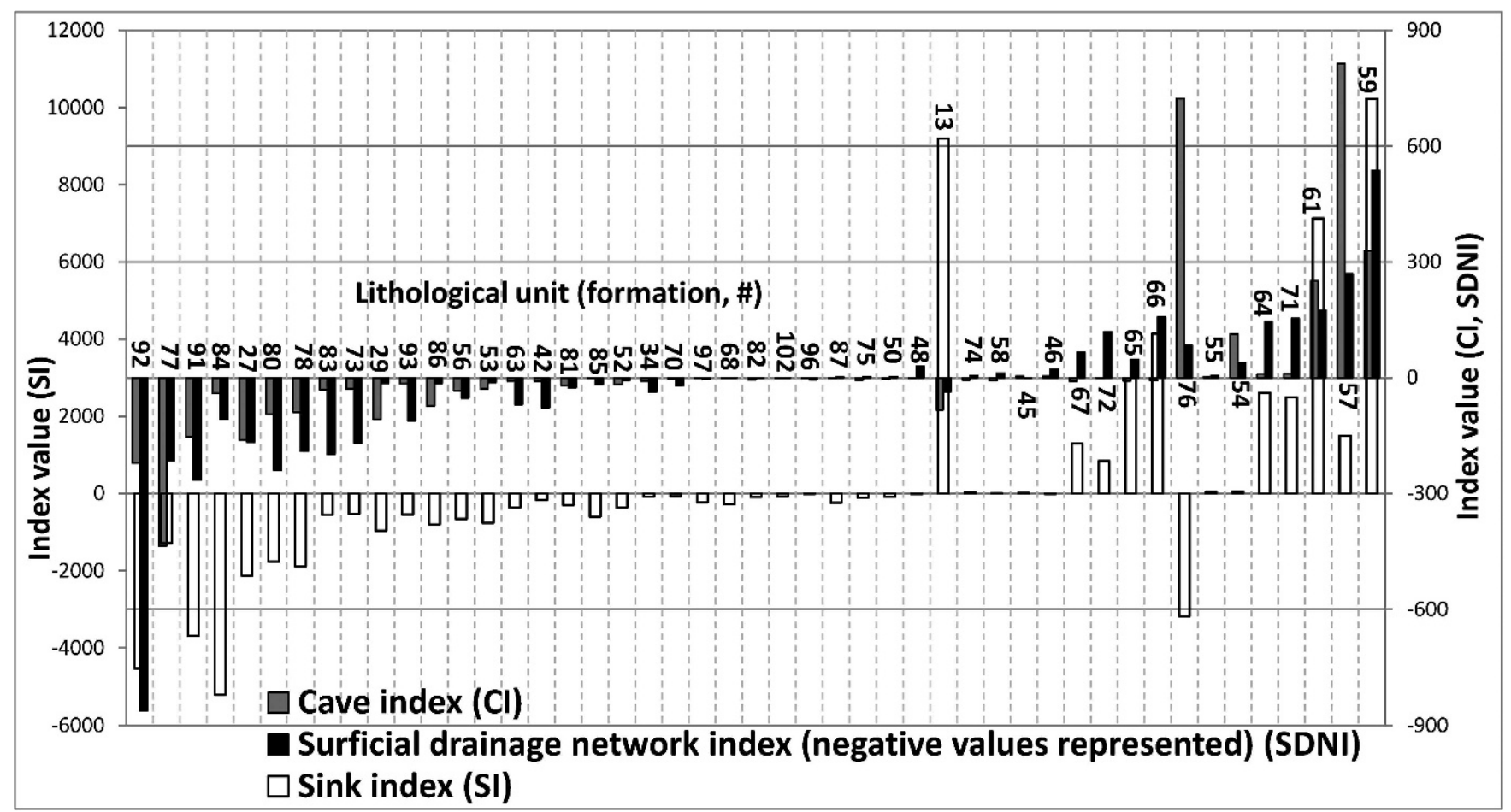

Figure 3. Cave, sink, and surface drainage network density index values, computed as described in the text, for each stratigraphic unit included in the analyses. Units are arranged from left according to increasing average normalized index (ANI; see text). Units determined to be intensely karstified are to the right of conspicuous unit 13.

occurrence of sinks is lower and the correlation between sink occurrence distribution and slope angle distribution was -0.797. This agrees with Gams (2003, p. 170), who claims that the occurrence of sinks has a negative correlation with slope angle. In addition to its greater slopes, unit 76 is located at relatively high elevation, an average of $1200 \mathrm{~m}$, while the average elevation of all the other intensely karstified units is $708 \mathrm{~m}$. The steeper slopes that result in higher surface runoff, extreme conditions of precipitation, winds, and temperature variations, and the absence of vegetation cover at high elevations could hinder the development of sinks.

High surface drainage network values, corresponding to small amounts of surface drainage, agree well with the selection of highly karstified units. As expected from field observations, high SDNI values are related to two lithological classes, limestones and mixed limestone and dolomite. The reason is rather trivial; units classified as limestones or limestones and dolomites have little or no soil cover that would, to some extent, prevent vertical percolation of water through small cracks and fractures to the subsurface. Where considerable surface drainage flow is present, there are usually fluvial sediments, and on the geological map such areas are labeled as Quaternary alluvial sediments.

Table 3 shows some of the data in Tables 1 and 2 averaged over the stratigraphic units, both as divided into less karstified units and intensely karstified units and as divided into the lithological classes clastic, dolomite, limestone, and mixed limestone and dolomite. Index and density values clearly show the distinction between classes that have higher (limestone and mixed limestone and dolomites) and lower (clastics and dolomites) karstification intensities. Nevertheless, the comparison of lithologic class with karstification intensity shows that not all limestones, and to a lesser extent, not all mixed limestones and dolomites, can be simply classified as intensely karstified areas. The differentiation is clearly visible in a three-dimensional plot where axes are CI, SI, and SDNI values (Fig. 4). The low average normalized indexes of nine units classified as limestone and one unit classified as limestones and dolomites that are exceptions (see Table 2 ) could be due to thin (5 to $10 \mathrm{~cm}$ ) bedding with total thicknesses of several meters up to only 30 meters (unit 63), to high content of intercalations in limestone such as quartzite pebbles, marls, cherts, and sandstones (units 29, 73, 96), siltstones and sandstones (unit 97), or siltstones and marls (unit 102), or to very steep average slopes above $20^{\circ}$ (units $70,75,85,87$ ). The last possibility is supported by the fact that the correlation of sink density with slope angle for limestone and mixed limestone and dolomite, among units with at least one positive index, is -0.797 . The effect of the slopes of those limestone and mixed carbonate units in which the actual sink occurrence is much lower than expected $(63,70,75,85$, and 87 ), is probably exaggerated by the fact that these units cover small areas where a low number of caves have been discovered, and result in low ANI values. Based on results of sink distribution analyses within slope ranges, critical 
Table 3. Average values of indexes (CI, cave index; SI, sink index; SDNI, surface drainage network index), the average normalized index (ANI), and other parameters over the stratigraphic units by lithological class $(\mathrm{C}=$ clastic rocks; $\mathrm{D}=$ dolomite; $\mathrm{L}=$ limestone; $\mathrm{LD}=$ mixed limestone and dolomite) and by degree of karstification (LKA, less karstified area; IKA, intensely karstified area).

\begin{tabular}{lrrrcccccc}
\hline $\begin{array}{l}\text { Rock } \\
\text { Type }\end{array}$ & \multicolumn{1}{c}{ CI } & \multicolumn{1}{c}{ SI } & \multicolumn{1}{c}{ SDNI } & ANI & $\begin{array}{c}\text { Elevation } \\
(\mathrm{m} \text { a.s.l. })\end{array}$ & $\begin{array}{c}\text { Slope angle } \\
(\text { degrees })\end{array}$ & $\begin{array}{c}\text { Cave density } \\
\left(\mathrm{km}^{-2}\right)\end{array}$ & $\begin{array}{r}\text { Sink density } \\
\left(\mathrm{km}^{-2}\right)\end{array}$ & $\begin{array}{c}\text { SDN density } \\
\left(\mathrm{km} / \mathrm{km}^{2}\right)\end{array}$ \\
\hline C & -51.11 & -180.67 & -122.59 & 0.387 & 688.6 & 16.9 & 0.18 & 7.13 & 1.52 \\
D & -134.44 & -2235.46 & -150.32 & 0.314 & 743.6 & 19.95 & 0.33 & 6.15 & 1.13 \\
L & 73.33 & 215.11 & 22.38 & 0.464 & 774 & 16.12 & 1.25 & 15.01 & 0.36 \\
LD & 84.66 & 3250.41 & 159.49 & 0.565 & 628.6 & 11.38 & 1.19 & 25.03 & 0.13 \\
LKA & -54.25 & -616.08 & -93.28 & 0.533 & 708.8 & 18.8 & 0.06 & 6.25 & 1.26 \\
IKA & 138.67 & 1888.21 & 114.84 & 0.382 & 678.6 & 13.5 & 1.47 & 20.93 & 0.19 \\
\hline
\end{tabular}

slope angles above which sinks are unlikely to develop at a $95 \%(99 \%)$ probability level, are $17^{\circ}\left(21^{\circ}\right)$ for unit $63,15^{\circ}$ $\left(20^{\circ}\right)$ for unit $70,20^{\circ}\left(22^{\circ}\right)$ for unit $75,23^{\circ}\left(26^{\circ}\right)$ for unit 85 , and $19^{\circ}\left(25^{\circ}\right)$ for unit 87 . In each case, the $95 \%$ slope-angle values are either somewhat lower than the average slope angles for a given unit $\left(23.5^{\circ}\right.$ for unit $63,20.1^{\circ}$ for unit 70 , $28.8^{\circ}$ for unit $85,20.3^{\circ}$ for 87 ) or much lower than the average slope angle $\left(32.3^{\circ}\right.$ for unit 75$)$. This remains true even for the $99 \%$ threshold, except in unit 87 . The distribution of sink occurrence on shallower slopes in units 63, $70,75,85$, and 87 that have relatively high average slope angles, indicates that the sparse occurrence of sinks within these units could be related to those high average slopes.

In the intensely karstified areas, the average density of caves is about 25 times greater than in less karstified areas (Table 3).

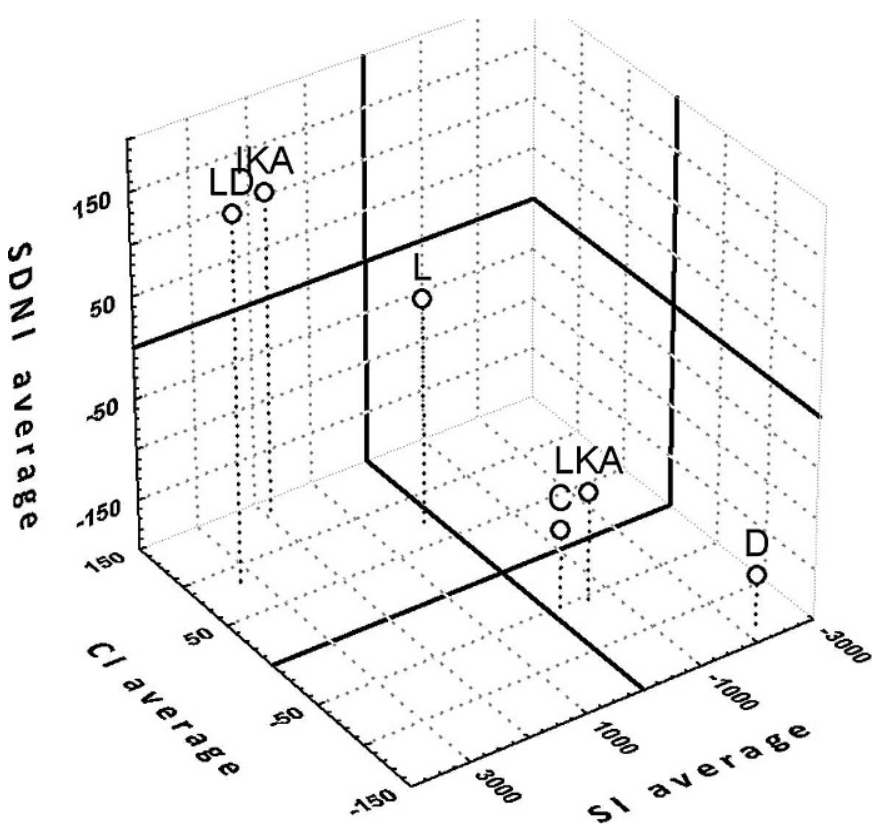

Figure 4. 3D plot of average values of the three indexes over the analyzed units sorted by lithology $(C$, clastic rocks; $D$, dolomites; L, limestones; LD, mixed limestone and dolomite) and by degree of karstification (LKA, less karstified areas; IKA, intensely karstified areas), as given in Table 3.
For sink density, the ratio between intensely and less karstified areas is greater than 3. Surface drainage network density in intensely karstified areas is almost 7 times lower than in less karstified areas.

Results of the analyses are best comprehended if displayed graphically. Figure 5 shows maps of the three feature indexes, for caves, sinks, and surface drainage network, in parts $\mathrm{A}-\mathrm{C}$, and the result of combining the data into average normalized indexes in part $\mathrm{D}$. The difference between the sink index SI and the other two indexes is most obvious in the Alpine region in the northwest and the north-central Quaternary terraces. The summary Figure 5D, showing the ANI values divided into the two karstification-intensity classes, shows that $23.9 \%$ of Slovenia's area (outcrops of sixteen stratigraphic units represented by 550 polygons that cover $4850.35 \mathrm{~km}^{2}$ ) can be classified as intensely karstified and $20.8 \%$ (thirty-one units represented by 1498 polygons covering $4216.36 \mathrm{~km}^{2}$ ) can be classified as less karstified.

\section{CONCLUSIONS}

The results derived by GIS for Slovenia show that it is possible, using a combination of appropriate indicative features, to identify hypergenic karst areas, and to a certain extent, also assess the degree of their karstification. We've shown that useful parameters are lithology, sink and cave density, and the absence of a surficial drainage network. Among some of these parameters, we noticed some correlation. We've also shown a general negative correlation between slope angles and sink density with high reliability. Average densities of caves, sinks, and surface drainage networks in intensely karstified areas are several times higher for the first two and several times lower for the latter than in less karstified areas. The results presented show regional karstification levels can vary on a local scale in comparison to the general scale.

The map in Figure 5D provides a basis for the general assessment of groundwater vulnerability, which is especially high in the karstified areas, and for water-resource protection planning. In addition, the map could be used in preliminary studies of land-planning issues such as the siting of

Journal of Cave and Karst Studies, December 2012 •259 

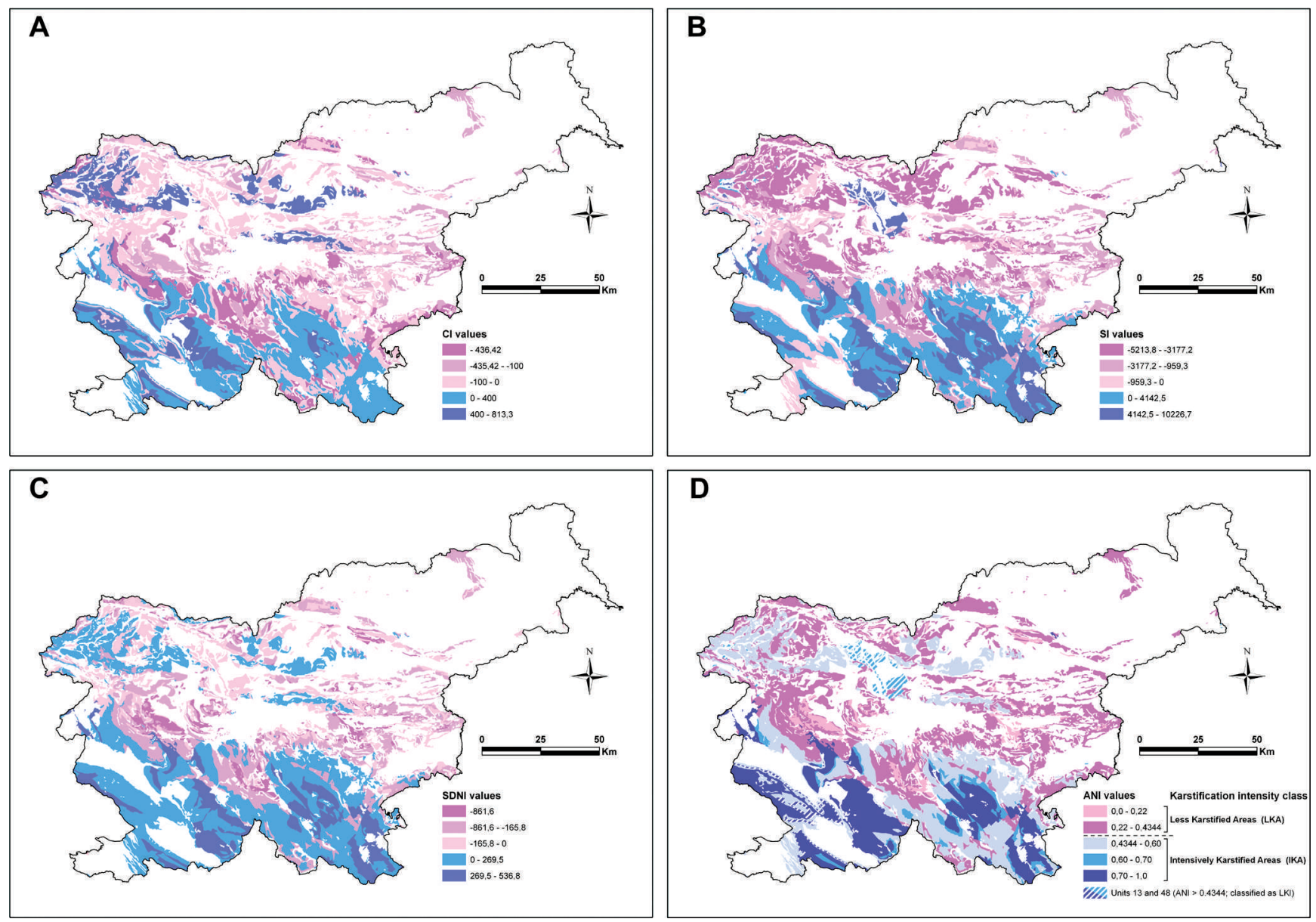

Figure 5. Maps of the analyzed areas, with colors based on A, cave index (CI); B, sink index (SI); C, surface drainage network density index (SDNI); and D, average normalized index (ANI). In D, the division between less and intensely karstified areas is shown in the key; units13 and $\mathbf{4 8}$ are shown hatched because they are classified as less karstified, despite their ANI values.

problematic infrastructure (landfills, industrial plants, gas stations, etc.) or for assessment of karst hazards in engineering geology. But the limitations of the presented approach need to be taken into account, including the coarse scale of the geological data, the low digital-elevation-model resolution, and problems with the automated derivation of surface karst from the DEM. The results can be used as guidance at a regional scale to prioritize areas of future more detailed assessment of local karst areas.

\section{ACKNOWLEDGEMENTS}

The authors wish to thank the Slovenian Research Agency for funding the project "A spatial model of groundwater hydrochemical composition in Slovenia in GIS environment" within which this research was performed.

\section{REFERENCES}

Armstrong, B., Chan, D., Collazos, A., and Mallams, J.L., 2003, Doline and aquifer characteristics within Hernando, Pasco, and northern Hillsborough counties: GSA Annual Meeting, Seattle, November 2-5, 2003, p. 39-51.
ARSO, 2005, European Environmental Information and Observation Network (Evropsko okoljsko informacijsko in opazovalno omrežje), Ljubljana, Environmental Agency of Republic of Slovenia: http://nfp-si.eionet.europa.eu/Dokumenti/GIS/ (accessed April 10, 2010).

Blaeu, W., and Blaeu, J., 1645, Karstia, Carniola, Histria et Windorum Marchia, in Theatrum Orbis Terrarum, sive Atlas Novus in quo Tabulæ et Descriptiones Omnium Regionum, Editæ a Guiljel et Ioanne Blaeu: http://www.library.ucla.edu/yrl/reference/maps/blaeu/ index.htm\#description (accessed August 21, 2010)

Buser, S., 2010, Geological Map of Slovenia at scale 1:250,000 (Geološka karta Slovenije $1: 250.000$ ): Geological Survey of Slovenia, 1 sheet.

Denizman, C., 2003, Morphometric and spatial distribution parameters of karstic depressions, lower Suwannee River basin, Florida: Journal of Cave and Karst Studies, v. 65, no. 1, p. 29-35.

Florea, L.J., 2005, Using state-wide GIS data to identify the coincidence between sinkholes and geologic structure: Journal of Cave and Karst Studies, v. 67, no. 2, p. 120-124.

Florea, L.J., Paylor, R.L., Simpson, L., and Gulley, J., 2002, Karst GIS advances in Kentucky: Journal of Cave and Karst Studies, v. 64, no. 1, p. 58-62.

Gams, I., 2003, Kras v Sloveniji v prostoru in času: Ljubljana, ZRC SAZU, $487 \mathrm{p}$

Gao, Y., and Zhou, W., 2008, Advances and challenges of GIS and DBMS applications in karst: Environmental Geology, v. 54, p. 901-904. doi:10.1007/s00254-007-0894-4.

GURS, 2005, Digital elevation model - DMV25, 1998-2005 (DEM with resolution $25 \times 25 \mathrm{~m}$ ), Surveying and Mapping Authority of the Republic of Slovenia. 
JZS, 2010, Catalog of caves in Slovenia: Speleological Association of Slovenia. Komac, M., 2005, Statistics of the Geological Map of Slovenia at scale 1:250 000: Geologija, v. 48, no. 1, p. 117-126.

Monroe, W.H., 1970, A Glossary of Karst Terminology: U.S. Geological Survey, Water-Supply Paper 1899, 26 p.

Stafford, K.W., Rosales-Lagarde, L., and Boston, P.J., 2008, Castile evaporite karst potential map of the Gypsum Plain, Eddy County, New Mexico and Culberson County, Texas: A GIS methodological comparison: Journal of Cave and Karst Studies, v. 70, no. 1, p. 35-46.
Taylor, C.J., Nelson, H.L. Jr., Hileman, G., and Kaiser, W.P., 2005, Hydrogeologic-framework mapping of shallow, conduit-dominated karst-Components of a regional GIS-based approach, in Kuniansky, E.L., ed., U.S. Geological Survey Karst Interest Group Proceedings. Rapid City, South Dakota, September 12-15, 2005, U.S. Geological Survey, Scientific Investigations Report 2005-5160, p. 103-113.

Valvasor, J.V., 1977, Slava vojvodine Kranjske: Ljubljana, Mladinska knjiga, $365 \mathrm{p}$.

Veni, G., 2002, Revising the karst map of the United States: Journal of Cave and Karst Studies, v. 64, no. 1, p. 45-50. 